\title{
Measurement of the Nickel/Nickel Oxide Transition in Ni-Cr-Fe Alloys and Updated Data and Correlations to Quantify the Effect of Aqueous Hydrogen on Primary Water SCC
}

Steven A. Attanasio and David S. Morton

This report was prepared as an account of work sponsored by the United States Government. Neither the United States, nor the United States Department of Energy, nor any of their employees, nor any of their contractors, subcontractors, or their employees, makes any warranty, express or implied, or assumes any legal liability or responsibility for the accuracy, completeness or usefulness of any information, apparatus, product or process disclosed, or represents that its use would not infringe privately owned rights. 


\title{
Measurement of the Nickel/Nickel Oxide Transition in Ni-Cr-Fe Alloys and Updated Data and Correlations to Quantify the Effect of Aqueous Hydrogen on Primary Water SCC
}

\author{
Steven A. Attanasio and David S. Morton \\ Lockheed Martin, Schenectady, NY 12301
}

\begin{abstract}
Alloys 600 and X-750 have been shown to exhibit a maximum in primary water stress corrosion cracking (PWSCC) susceptibility, when testing is conducted over a range of aqueous hydrogen $\left(\mathrm{H}_{2}\right)$ levels. Contact electric resistance (CER) and corrosion coupon testing using nickel specimens has shown that the maximum in SCC susceptibility occurs in proximity to the nickel/nickel oxide $(\mathrm{Ni} / \mathrm{NiO}$ ) phase transition. The measured location of the $\mathrm{Ni} / \mathrm{NiO}$ transition has been shown to vary with temperature, from $25 \mathrm{scc} / \mathrm{kg} \mathrm{H} \mathrm{H}_{2}$ at $360^{\circ} \mathrm{C}$ to $4 \mathrm{scc} / \mathrm{kg} \mathrm{H} \mathrm{H}_{2}$ at $288^{\circ} \mathrm{C}$. New CER measurements show that the $\mathrm{Ni} / \mathrm{NiO}$ transition is located at $2 \mathrm{scc} / \mathrm{kg} \mathrm{H} \mathrm{H}_{2}$ at $260^{\circ} \mathrm{C}$. An updated correlation of the phase transition is provided. The present work also reports CER testing conducted using an Alloy 600 specimen at $316^{\circ} \mathrm{C}$. A large change in resistance occurred between 5 and $10 \mathrm{scc} / \mathrm{kg} \mathrm{H}$, similar to the results obtained at $316^{\circ} \mathrm{C}$ using a' nickel specimen. This result adds confidence in applying the $\mathrm{Ni} / \mathrm{NiO}$ transition measurements to $\mathrm{Ni}-\mathrm{Cr}-\mathrm{Fe}$ alloys. The understanding of the importance of the Ni/NiO transition to PWSCC has been used previously to quantify $\mathrm{H}_{2}$ effects on $\mathrm{SCC}$ growth rate (SCCGR). Specifically, the difference in the electrochemical potential $(\mathrm{EcP})$ of the specimen or component from the $\mathrm{Ni} / \mathrm{NiO}$ transition (i.e., $\mathrm{EcP}_{\mathrm{Ni} \mathrm{NiO}}-\mathrm{EcP}$ ) has been used as a correlating parameter. In the present work, these SCCGR-H $\mathrm{H}_{2}$ correlations, which were based on SCCGR data obtained at relatively high test temperatures $\left(338\right.$ and $\left.360^{\circ} \mathrm{C}\right)$, are evaluated via SCCGR tests at a reduced temperature $\left(316^{\circ} \mathrm{C}\right)$. The $316^{\circ} \mathrm{C}$ data are in good agreement with the predictions, implying that the SCCGR- $\mathrm{H}_{2}$ correlations extrapolate well to reduced temperatures. The SCCGR- $\mathrm{H}_{2}$ correlations have been revised to reflect the updated $\mathrm{Ni} / \mathrm{NiO}$ phase transition correlation. New data are presented for EN82H weld metal (also known as Alloy 82) at $338^{\circ} \mathrm{C}$. Similar to other nickel alloys, SCC of EN82H is a function of the aqueous $\mathrm{H}_{2}$ level, with the SCCGR exhibiting a maximum near the $\mathrm{Ni} / \mathrm{NiO}$ transition. For example, the SCCGR at $8 \mathrm{scc} / \mathrm{kg} \mathrm{H}_{2}$ is $\sim 8.1 \mathrm{x}$ higher than at $60 \mathrm{scc} / \mathrm{kg} \mathrm{H} \mathrm{H}_{2}$. The 8 scc/ $/ \mathrm{kg} \mathrm{H}_{2}$ condition is near the $\mathrm{Ni} / \mathrm{NiO}$ transition (located at $\sim 14 \mathrm{scc} / \mathrm{kg} \mathrm{H}_{2}$ at $338^{\circ} \mathrm{C}$ ), while $60 \mathrm{scc} / \mathrm{kg} \mathrm{H} \mathrm{H}_{2}$ is well into the nickel metal regime. A hydrogen-SCCGR correlation is provided for EN82H. The data and understanding obtained from the present work show that $\mathrm{SCC}$ can be mitigated by adjusting the aqueous $\mathrm{H}_{2}$ level. For example, SCCGR is typically minimized at relatively high aqueous $\mathrm{H}_{2}$ levels, that are well into the nickel metal regime (i.e., far from the $\mathrm{Ni} / \mathrm{NiO}$ transition).
\end{abstract}

\section{Introduction}

Testing of nickel-based alloys at various aqueous $\mathrm{H}_{2}$ levels and temperatures has shown that a maximum in PWSCC susceptibility exists in proximity to the $\mathrm{Ni} / \mathrm{NiO}$ equilibrium. ${ }^{1-12}$ The theory that the stability of $\mathrm{NiO}$ influences PWSCC is supported by microscopy studies in which the crack tip oxide often exhibits a $\mathrm{NiO}$ crystal structure (i.e., $\mathrm{Ni}(\mathrm{Cr}, \mathrm{Fe}) \mathrm{O}$ ) as opposed to the spinel structure oxides (i.e., $\mathrm{Ni}_{x} \mathrm{Fe}_{1 \times x} \mathrm{Cr}_{\mathrm{y}} \mathrm{Fe}_{2-\mathrm{y}} \mathrm{O}_{4}$ ) typically found on the external metal surface. ${ }^{13}$ Spinel structure oxides have also been observed at the crack tip in some cases. ${ }^{14}$ Changing the aqueous $\mathrm{H}_{2}$ level can stabilize or destabilize $\mathrm{NiO}$, due to the reaction between $\mathrm{NiO}$ and $\mathrm{H}_{2}$ (i.e., $\mathrm{NiO}+\mathrm{H}_{2}=\mathrm{Ni}+\mathrm{H}_{2} \mathrm{O}$ ). CER measurements of the Ni/NiO phase transition ${ }^{15}$ have been used to quantify $\mathrm{H}_{2}$ effects on SCCGR, based on the understanding that that the $\mathrm{H}_{2}$ dependency can be fundamentally described by the extent that the EcP of the alloy deviates from the potential of the $\mathrm{N} / \mathrm{NiO}$ transition (i.e., $\left.\mathrm{EcP}_{\mathrm{NiNiO}}-\mathrm{EcP}\right)$. This potential difference $(\triangle \mathrm{EcP})$ likely represents the relative stability of oxides that can influence SCC. SCCGR- $\mathrm{H}_{2}$ correlations were developed for Alloys $600, \mathrm{X}-750 \mathrm{HTH}$ and X-750 AH in terms of the parameter $\triangle \mathrm{EcP}^{4}{ }^{4}$ Knowledge of the location of the Ni/NiO phase transition as a function of temperature allows these correlations to be extrapolated to lower temperatures via the assumption that the magnitude of the dissolved $\mathrm{H}_{2}$ effect is temperature independent (i.e., it is assumed that the only effect of temperature is to change the location of the $\mathrm{Ni} / \mathrm{NiO}$ phase transition). Using these correlations, SCCGR effects can be predicted at a given aqueous $\mathrm{H}_{2}$ level and temperature, for each material tested.

\section{Experimental Procedure}

Environment: Testing was conducted in deaerated water at a high temperature $\mathrm{pH}$ of $\sim 7$. The desired $\mathrm{H}_{2}$ levels were obtained by varying the feed tank $\mathrm{H}_{2}$ overpressure according to Henry's law. The room temperature $\mathrm{H}_{2}$ 
calculations were conducted using a Henry's law coefficient ${ }^{16}$ of $0.85 \mathrm{psia} /(\mathrm{scc} / \mathrm{kg})$. Mixed gas of 4 or $14.7 \%$ hydrogen with the balance being argon was used to obtain coolant hydrogen levels less than $20 \mathrm{scc} / \mathrm{kg} \mathrm{H}$.

CER Measurements: The CER method ${ }^{17-19}$ can be used to analyze surface resistance in metal-environment systems. Figure 1 shows a schematic diagram of the CER instrument used in the present work. The test specimen was nickel ( $99.5 \mathrm{wt} \%$ ) at $260^{\circ} \mathrm{C}$ and Alloy 600 at $316^{\circ} \mathrm{C}$. Iridium was used as an oxide-free, inert specimen in both cases. Testing details have been provided previously. ${ }^{\text {Is }}$ Pre-test specimen processing was conducted to minimize film formation. The specimen tips were polished using grinding paper prior to each test run. The specimens were then pushed together prior to admitting water to the system. A cathodic current $(\sim-100 \mu \mathrm{A})$ was then applied until the specimen reached its intended pressure and temperature, at which time the CER test was started.

Hydrogen fugacitu measurements: 'Testing was performed at $260^{\circ} \mathrm{C}$ in the CER facility using a silver-palladium tube, as a spot-check to ensure that the $\mathrm{H}_{2}$ levels in the test facility were properly controlled. Testing was conducted at an autoclave pressure of $1800 \mathrm{psi}$. Details of the experimental apparatus and test method have been provided. ${ }^{20}$

Electrochemical measurements: EcPs were measured on electrically isolated specimens $v s$. a platinum $(\mathrm{Pt})$ electrode as well as (in some cases) a yttria-stabilized zirconia-iron/iron oxide ( $\mathrm{YSZ}-\mathrm{Fe} / \mathrm{Fe}_{3} \mathrm{O}_{4}$ ) electrode. Prior work has shown that the $\mathrm{YSZ}-\mathrm{Fe} / \mathrm{Fe}_{3} \mathrm{O}_{4}$ probe is an effective reference electrode in simulated primary water. ${ }^{20}$

Materials for SCCGR Tests: This study investigated EN82H weld metal, mill-annealed Alloy 600, and Alloy X-750 in the $\mathrm{AH}$ heat treatment. Alloys 600 and X-750 $\mathrm{AH}$ were tested at $316^{\circ} \mathrm{C}$ and at initial $\mathrm{K}_{1}$ levels of $65.9 \mathrm{MPa} \mathrm{m}$ (Alloy 600 ) and $39.5 \mathrm{MPa} / \mathrm{m}(\mathrm{X}-750 \mathrm{AH}$ ). Additional test details for Alloys 600 and X-750 AH are provided in Reference 4. The composition of the EN82H material is listed in Table 1. The yield strength of the as-deposited weld metal is $397 \mathrm{MPa}$. EN82H material was deposited via the gas tungsten arc welding process, using $100 \%$ argon as a shield gas. Weld metal was deposited into a 'weld pad' geometry (i.e., using a baseplate but no sidewall materials). The EN82H weld pad was fabricated into standard $25.4 \mathrm{~mm}$ thick compact tension (CT) specimens with $10 \%$ side grooves. Specimen orientation was such that crack growth occurred from the root to the crown of the weld, with the loading axis perpendicular to the direction of welding. In ASTM notation, this orientation is referred to as T-S, as described previously. ${ }^{21}$ Specimens were air fatigue precracked to an initial a/ $\mathrm{W}$ of 0.5 , using the fatigue precracking procedure from ASTM E399 Annex 2. A 10 minute, 10\% daily unload was performed. EN82H tests were conducted at $338^{\circ} \mathrm{C}$, an autoclave pressure of $2500 \mathrm{psi}$, at an initial $\mathrm{K}_{\mathrm{I}}$ level of $38.5 \mathrm{MPa} \mathrm{V}_{\mathrm{m}}$, and at hydrogen levels ranging from $\sim 0.1$ to $120 \mathrm{scc} / \mathrm{kg} \mathrm{H}$.

SCCGR Tests: Tests were conducted in active load servoelectric machines with digital control electronics monitored through a computerized data acquisition system. A description of the recirculating high flow rate autoclave system has previously been provided. ${ }^{22}$ EN82H specimens were preconditioned with no applied load at $260^{\circ} \mathrm{C}$ for 1 week at the test hydrogen concentration. Crack lengths were monitored in-situ using electrical potential drop according to ASTM E647, Annex 3, and using front-face linear variable displacement transformers (LVDTs). However, neither type of instrumentation was successful in detecting the onset of crack growth, which is not unusual for the irregular crack fronts associated with weld metal SCC. SCCGRs were based on post-test destructive examination (DE) data. Upon completion of testing, all specimens were heat-tinted in air at $454^{\circ} \mathrm{C}$ for 8 hours to facilitate fractographic inspections. The Alloy 600 and EN82H specimens were fatigued apart to minimize deformation of the SCC surface, and were then pulled apart in tension. The higher strength X-750 specimens were simply pulled apart in tension. The amount of SCC in each specimen was measured by optical examination using the procedure in ASTM E813. Due to the typically irregular nature of SCC cracks in weld metal, 30 measurement locations were used across the crack front. Crack growth rates were determined by dividing the average SCC extension by the test duration.

\section{Results and Discussion}

\section{CER Testing using a Nickel Specimen}

In this test, which was conducted at $260^{\circ} \mathrm{C}$, the initial $\mathrm{H}_{2}$ level was $60 \mathrm{scc} / \mathrm{kg} \mathrm{H}_{2}$, which is well into the rickel metal stability regime based on prior data at $288^{\circ} \mathrm{C}$. As shown in Figure 2, a very low resistance $(\sim 0.001 \Omega)$ was observed, consistent with previously measured Ni regime values. ${ }^{95}$ From this point, the $\mathrm{H}_{2}$ level was decreased incrementally, to determine the $\mathrm{H}_{2}$ level at which an increase in resistance (corresponding to oxidation) occurred. Very low resistances were measured at $60,30,5$, and $2 \mathrm{scc} / \mathrm{kg} \mathrm{H}_{2}$. Data were lost due to an interruption in power between 767 and 797 hours. Although an apparent minor increase in resistance was observed when the power was restored, this increase is not real. As explained previously, ${ }^{15}$ this apparent increase is due to the drifting apart of the 
specimens, as confirmed by readjusting the 'home' position (i.e., re-setting the gap) of the specimens at 863 hours. Reducing the $\mathrm{H}_{2}$ level from 2 to $1 \mathrm{scc} / \mathrm{kg}$ at 984 hours led to a steady increase in resistance for $\sim 18$ days, at which time the $\mathrm{H}_{2}$ level was increased to $3 \mathrm{scc} / \mathrm{kg}$. This change in the $\mathrm{H}_{2}$ level caused a clear decrease in resistance, within 0.5 hours after the feedtank $\mathrm{H}_{2}$ pressure was increased. Summary data are provided in Table 2 .

It is evident that at $260^{\circ} \mathrm{C}, 1 \mathrm{scc} / \mathrm{kg} \mathrm{H}_{2}$ resides in the nickel oxide stability regime and that 60,20 , and $3 \mathrm{scc} / \mathrm{kg} \mathrm{H}$ are located in the nickel stability regime. It is not as straightforward to assess the condition of $2 \mathrm{scc} / \mathrm{kg} \mathrm{H} \mathrm{H}_{2}$. Figure 2 shows that no evident film formation occurred at this condition for 146 hours. Since oxide formation could have occurred at longer times, however, it is difficult to classify $2 \mathrm{scc} / \mathrm{kg} \mathrm{H} \mathrm{H}_{2}$ as residing within either the nickel or nickel oxide stability regime. Since $1 \mathrm{scc} / \mathrm{kg} \mathrm{H}_{2}$ is known to be in the nickel oxide regime and $3 \mathrm{scc} / \mathrm{kg} \mathrm{H}_{2}$ is known to be in the nickel stability regime, it seems reasonable to define the transition hydrogen level at $260^{\circ} \mathrm{C}$ as $2 \pm 1 \mathrm{scc} / \mathrm{kg} \mathrm{H}$.

Figure 3 shows a summary plot of CER measurements performed from 260 to $360^{\circ} \mathrm{C}$ using nickel specimens, from the present work and reference 15 . Data are also shown from corrosion coupon tests at $338^{\circ} \mathrm{C} .(12.5$ and $20 \mathrm{scc} / \mathrm{kg}$ $\mathrm{H}_{2}$ ), which were used to spot-check the CER measurements. In addition to the data shown in Figure 3 , half of the nickel coupon which formed an oxide during exposure at $12.5 \mathrm{scc} / \mathrm{kg} \mathrm{H} \mathrm{H}_{2}\left(338^{\circ} \mathrm{C}\right)$ was re-exposed at $20 \mathrm{scc} / \mathrm{kg} \mathrm{H}$ $\left(338^{\circ} \mathrm{C}\right.$ ), and significant film reduction was observed. ${ }^{15}$ Figure 3 also contains a thermodynamic model of the phase transition, which was obtained via regression to the experimental data, as discussed below.

\section{In-Autoclave Hydrogen Fugacity Measurements at $260^{\circ} \mathrm{C}$}

Testing was performed at $260^{\circ} \mathrm{C}$ in the CER facility at hydrogen levels of $1,5,30$, and $60 \mathrm{scc} / \mathrm{kg} \mathrm{H}_{2}$. Steady-state pressures, as reported previously, ${ }^{20}$ were very consistent with the expected values using a Henry's law coefficient from Reference 16. The present work utilizes an improved Henry's law correlation from Moshier and Witt. ${ }^{23}$ Table 4 shows that the measured hydrogen fugacity values are very similar to the hydrogen fugacity values calculated using this updated Henry's law correlation. This good agreement between measured and expected hydrogen fugacity values demonstrates that there are no spurious at-temperature sources or sinks of hydrogen causing the autoclave hydrogen concentration to be significantly different than the feedtank concentration.

\section{Updated Thermodynamic Model for the Nickel/Nickel Oxide Phase Transition}

In Reference 4, CER and corrosion coupon data were used to develop a two-parameter thermodynamic model for the $\mathrm{Ni} / \mathrm{NiO}$ transition. The model is updated herein to incorporate the new CER data at $260^{\circ} \mathrm{C}$, plus an improved Henry's law comelation. ${ }^{23}$ (Note that this Henry's law correlation was developed by Moshier and Witt ${ }^{23}$ by performing hydrogen fugacity measurements at various temperatures and autoclave pressures, and then fitting the data to the Krichevsky-Kasarnovsky equation from Reference 24.) The model is developed using a thermodynamic equation for the phase transition reaction $\left(\mathrm{Ni}+\mathrm{H}_{2} \mathrm{O}=\mathrm{NiO}+\mathrm{H}_{2}\right.$ ). Specifically:

$$
\Delta G=\Delta H_{298}-T \cdot \Delta S_{298}=-R \cdot T \cdot \ln \left(f_{H_{2}}\right)
$$

where $\Delta G$ is the Gibbs free energy, $\Delta H_{298}$ and $\Delta S_{298}$ are the enthalpy and entropy of formation for the phase transition reaction, $R$ is the universal gas constant $(8.314 \mathrm{~J} / \mathrm{mol}-\mathrm{K}), T$ is the temperature in Kelvin, and $f_{H 2}$ is the hydrogen fugacity in atmospheres (note that the activities of $\mathrm{Ni}, \mathrm{H}_{2} \mathrm{O}$, and $\mathrm{NiO}$ are $\cong 1$ ). Rearranging [1] yields:

$$
\ln f_{H_{2}}=-\frac{\Delta H_{298}}{R}\left(\frac{1}{T}\right)+\frac{\Delta S_{298}}{R}
$$

Figure 4 shows an empirical fit of the measured $\mathrm{Ni} / \mathrm{NiO}$ phase transition data to equation [2]. The hydrogen fugacity values corresponding to the measured $\mathrm{Ni} / \mathrm{NiO}$ phase transition were determined from the data in $\mathrm{Figure} 3$ (and listed in Table 5), plus the appropriate Henry's law coefficient ${ }^{23}$ for each test condition (Table 5). The parameters $\Delta H_{298}$ and $\Delta S_{298}$ were determined via linear regression to be $38,400 \mathrm{~J} / \mathrm{mol}$ and $43.5 \mathrm{~J} / \mathrm{mol}-\mathrm{K}$, respectively. Note that these values are different than those reported in Reference 4, since the model has been updated to account for the new data at $260^{\circ} \mathrm{C}$, and because different Henry's law coefficients were used. As compared to the Reference 
4 values, the updated values of $\Delta H_{298}$ and $\Delta S_{298}$ are closer to the 'theoretical' NiO thermodynamic values of 46,100 $\mathrm{J} / \mathrm{mol}$ and $68.0 \mathrm{~J} / \mathrm{mol}-\mathrm{K}$ obtained from thermodynamic tables. ${ }^{24}$

Thus, on a hydrogen fugacity basis, the thermodynamic model is:

$$
f_{H_{2}}=\exp (-4619.2 \cdot[1 / T]+5.2302)
$$

where $f_{H_{2}}$ is in atmospheres. The thermodynamic model can also be presented on a hydrogen concentration basis:

$$
\left[H_{2}\right]_{N i / N i O}=\frac{\exp (-4619.2 \cdot[1 / T]+5.2302)}{k_{H}}
$$

where $\left[H_{2}\right]_{M / N \text { No }}$ is the hydrogen concentration (in scc/kg) corresponding to the $\mathrm{Ni} / \mathrm{NiO}$ phase transition, and $k_{H}$ is the Henry's law coefficient at the temperature and pressure of interest in $\mathrm{atm} . /\left(\mathrm{scc} / \mathrm{kg} \mathrm{H} \mathrm{H}_{2}\right)$. Figure 3 and Table 5 show that the thermodynamic model provides a good approximation of the measured $\mathrm{Ni} / \mathrm{NiO}$ transition over the range of 260 to $360^{\circ} \mathrm{C}$.

\section{CER Testing using an Alloy 600 Specimen}

As described in reference 15 , several prior CER tests have been conducted at $316^{\circ} \mathrm{C}$ using a nickel specimen. These tests consistently showed a large increase in resistance when the $\mathrm{H}_{2}$ level was lowered from 10 to $5 \mathrm{scc} / \mathrm{kg} \mathrm{H}$, and a large decrease in resistance when the hydrogen level was raised back to $10 \mathrm{scc} / \mathrm{kg} \mathrm{H}$. Figure 5 shows that a similar pattern is evident for Alloy 600 in a test conducted at $316^{\circ} \mathrm{C}$. If one first focuses on the portion of the test starting at 306 hours (after the data loss due to home position problems), it is observed that a steady-state resistance was established for $\sim 24$ hours ( 306 to 330 hours) at $10 \mathrm{scc} / \mathrm{kg} \mathrm{H}$. At 330 hours, the hydrogen level was lowered to $5 \mathrm{scc} / \mathrm{kg} \mathrm{H}_{2}$. An increase in the resistance was noted within approximately 2 hours, and the resistance eventually increased by nearly two orders of magnitude at this condition. The $\mathrm{H}_{2}$ level was subsequently raised to $10 \mathrm{scc} / \mathrm{kg} \mathrm{H}$ at 478 hours. A nearly immediate decrease in resistance was observed, and this decrease continued for the next several days. Thus, there is a strong oxidation/reduction reaction (presumably related to nickel and its oxides) in the vicinity of 5 to $10 \mathrm{scc} / \mathrm{kg} \mathrm{H}_{2}$ at $316^{\circ} \mathrm{C}$ - this effect is noted whether the test specimen is pure nickel (as in reference 15 ) or Alloy 600 (as in the present work).

Although the nickel and Alloy 600 specimens tested at $316^{\circ} \mathrm{C}$ exhibited a similar trend when the hydrogen level was changed from 10 to $5 \mathrm{scc} / \mathrm{kg} \mathrm{H}_{2}$ and then back to $10 \mathrm{scc} / \mathrm{kg} \mathrm{H}$, it is noted that the absolute values of the resistances measured were quite different. In prior tests using a nickel specimen, the obtained resistance at $60 \mathrm{scc} / \mathrm{kg} \mathrm{H} \mathrm{H}_{2}$ was very low $(\sim 0.001$ to $0.002 \Omega)$. In the present Alloy 600 testing, the initial resistance value was low $(\sim 0.004 \Omega)$, presumably due to the efforts to minimize film formation prior to and during heatup (e.g., specimen polishing, pushing the specimen tips together to minimize water access, and application of a cathodic current). However, once the test temperature of $316^{\circ} \mathrm{C}$ was reached, the specimen gap was restored and the cathodic current was turned off. At this point, film growth occurred, as evidenced by the increasing resistance from 0 to $\sim 20$ test hours. After this point, the rate of change in resistance diminished. It is expected that a steady-state resistance value was reached sometime during the period of time where no data were available, given the fact that the resistance was extremely stable during the $\sim 1$ day period from 306 to 330 hours. It appears that an oxide film grew initially upon exposure of the Alloy 600 specimen to the $316^{\circ} \mathrm{C}$ water and then stabilized for at least 24 hours until the $\mathrm{H}_{2}$ level was decreased at 330 hours. Note that the oxide formed on the Alloy $600 \mathrm{CER}$ specimen was not analyzed, since such an analysis would be destructive in nature, and it was desirable to have the ability to perform future testing on the specimen.

Data from other investigators: CER data reported by Ehrnsten et al ${ }^{18}$ at $320^{\circ} \mathrm{C}$ using Alloy 600 as a test specimen is broadly consistent with the present Alloy 600 CER data. In their work, a large increase in resistance was observed when the amount of hydrogen was lowered from an at-temperature hydrogen partial pressure of 0.25 bars $\left(\sim 30 \mathrm{scc} / \mathrm{kg} \mathrm{H}_{2}\right)$ to a nitrogen $\left(\mathrm{N}_{2}\right)$-deaerated condition. When the hydrogen level was subsequently raised from the $\mathrm{N}_{2}$-deaerated condition to an at-temperature hydrogen partial pressure of $\left.0.6 \mathrm{bars},(\sim 72 \mathrm{scc} / \mathrm{kg} \mathrm{H})_{2}\right)$, a large decrease in resistance was observed. Examination of Figure 3 shows that at $320^{\circ} \mathrm{C}, 30$ and $72 \mathrm{scc} / \mathrm{kg} \mathrm{H}$ are on the 'reducing' 
side of the $\mathrm{Ni} / \mathrm{NiO}$ phase transition, while a $\mathrm{N}_{2}$ sparge condition (which was estimated as $\sim 0.1 \mathrm{scc} / \mathrm{kg} \mathrm{H}_{2}$ in a previous test in our laboratory') is on the 'oxidizing' side of the transition.

In their work, ${ }^{18}$ it was presumed that a spinel structure oxide was formed on the Alloy 600 specimen in the nitrogendeaerated condition. It was stated that the lower resistance values observed at the elevated hydrogen conditions may be due to stringers of metallic nickel in the oxide, which increase the electrical conductivity of the film. It was suggested that when the dissolved hydrogen level was reduced, the exposed part of these stringers may have been oxidized (e.g., to NiO), resulting in the observed increase in resistance. Ehrnsten et al ${ }^{18}$ note that the presence of metallic $\mathrm{Ni}$ in the oxide film growing on Alloy 600 in water containing hydrogen has been experimentally verified by Airey. ${ }^{25}$ While this explanation seems reasonable, it is noted that other investigators ${ }^{26}$ have shown that at short times, the oxide film on $\mathrm{Ni}-\mathrm{Cr}-\mathrm{Fe}$ alloys can assume a nickel oxide structure with iron and chromium incorporated within the oxide. In this case, the NiO structure oxide is metastable, and eventually transforms to a spinel structure.

In summary, while the oxide character and the electrochemical reactions taking place on Alloy 600 CER specimens when the hydrogen level is adjusted are not known with certainty, it seems reasonable to believe that oxidation of nickel within the film is likely playing a role. Additionally, the present CER data support the view that a large change in the oxidation/reduction behavior of Alloy 600 is occurring in the vicinity of the measured $\mathrm{Ni} / \mathrm{NiO}$ phase transition. This observation adds confidence in applying the $\mathrm{Ni} / \mathrm{NiO}$ transition measurements to $\mathrm{Ni}-\mathrm{Cr}-\mathrm{Fe}$ alloys.

\section{SCCGR Testing}

Alloy 600 at $316^{\circ} \mathrm{C}$ : Prior work ${ }^{4}$ on Alloy 600 was conducted at $338^{\circ} \mathrm{C}$ at initial $\mathrm{K}_{\mathrm{I}}$ values of 27.5 and $65.9 \mathrm{MPa} / \mathrm{m}$ (it was demonstrated that the $\mathrm{H}_{2}$ functionality was not appreciably influenced by the stress intensity factor). As described in Reference 4, a correlation was developed for Alloy 600 SCCGR, using the parameter EcP $\mathrm{N}_{\mathrm{NiNiO}}-\mathrm{EcP}$. One important question is whether this correlation extrapolates correctly to lower temperatures. The extrapolation ${ }^{4}$ was based on the assumption that the magnitude of the dissolved hydrogen effect is temperature independent. That is, it was assumed that the only effect of temperature is to change the location of the $\mathrm{Ni} / \mathrm{NiO}$ phase transition.

The testing performed in the present study was designed to evaluate the ability of the correlation to extrapolate to reduced temperatures. Figure 6 shows SCCGR data for Alloy 600 at a $\mathrm{K}_{\mathrm{I}}$ value of $65.9 \mathrm{MPa} / \mathrm{m}$, plotted using the parameter $\mathrm{EcP}_{\mathrm{NiNiO}}-\mathrm{EcP}$ (details for constructing plots using the $\mathrm{EcP}_{\mathrm{NiNiO}}-\mathrm{EcP}$ scale are provided later in this paper). The square symbols represent the prior data, which was generated at $338^{\circ} \mathrm{C}\left(640^{\circ} \mathrm{F}\right)$. The triangles are new data generated at $316^{\circ} \mathrm{C}\left(600^{\circ} \mathrm{F}\right)$, at hydrogen levels of 7,40 , and $120 \mathrm{sec} / \mathrm{kg} \mathrm{H}_{2}$. It is apparent that the $316^{\circ} \mathrm{C}$ data are in good agreement with the $338^{\circ} \mathrm{C}$ data. The magnitude of the hydrogen effect can be defined by the ratio between the maximum SCCGR and the minimum SCCGR at a specific temperature. At $316^{\circ} \mathrm{C}$, the SCCGR at 7 $\mathrm{scc} / \mathrm{kg} \mathrm{H}_{2}(0.151 \mathrm{mils} / \mathrm{day})$ is $\sim 2.7 \mathrm{x}$ greater than the SCCGR measured at $120 \mathrm{scc} / \mathrm{kg} \mathrm{H} \mathrm{H}_{2}(0.056 \mathrm{mils} /$ day $)$. Thus, the magnitude of the $\mathrm{H}_{2}$ effect is similar to that reported at $338^{\circ} \mathrm{C}(\sim 2.8 \mathrm{x}){ }^{4}$ The $316^{\circ} \mathrm{C}$ data are also consistent with the understanding that SCCGRs increase as the $\mathrm{Ni} / \mathrm{NiO}$ phase transition is approached, given that the CER-measured phase transition is $7.5 \pm 2.5 \mathrm{scc} / \mathrm{kg} \mathrm{H}_{2}$ at this temperature. Overall, Figure 7 supports the view that the correlation ${ }^{4}$ developed for Alloy 600 based on testing at $338^{\circ} \mathrm{C}$ is also appropriate for the $316^{\circ} \mathrm{C}$ data.

Comparison to Alloy 600 Data from Other Investigators: In a previous paper, ${ }^{15}$ the location of the measured $\mathrm{Ni} / \mathrm{NiO}$ phase transition was compared to data compiled by Cassagne et al. ${ }^{1}$ The present work compares the $\mathrm{Ni} / \mathrm{NiO}$ and SCCGR data to the work of other investigators. One study of particular interest is that of Totsuka, ${ }^{10}$ since this work evaluated the SCC response of Alloy 600 as a function of aqueous hydrogen level at two different temperatures. ${ }^{(1)}$ As shown in Figure 7, the SCC susceptibility exhibited a maximum at both temperatures, though the location of the susceptibility maximum changed from approximately $33 \mathrm{scc} / \mathrm{kg} \mathrm{H}_{2}$ at $360^{\circ} \mathrm{C}$ to approximately $11 \mathrm{scc} / \mathrm{kg} \mathrm{H}_{2}$ at $320^{\circ} \mathrm{C}$. The fact that the maximum in SCC susceptibility appears to reside at a lower hydrogen concentration at the lower temperature is qualitatively consistent with the view that proximity to the $\mathrm{Ni} / \mathrm{NiO}$ phase transition is a key

(1) The work of Totsuka et al. ${ }^{10}$ was performed using constant extension rate test (CERT) specimens, so the crack growth rates reported in these tests may be influenced by a finite crack incubation time. The specimens used by Totsuka et al. ${ }^{10}$ contain a significant amount of cold work due to cold pressing of the flat tensile specimens on a die. 
factor in the hydrogen dependency of PWSCC. Quantitatively, the location of the measured phase transition at $360^{\circ} \mathrm{C}\left(25 \mathrm{scc} / \mathrm{kg} \mathrm{H}_{2}\right)$ and at $320^{\circ} \mathrm{C}\left(\sim 8 \mathrm{scc} / \mathrm{kg} \mathrm{H}_{2}\right)$ is also in good agreement with the data of Totsuka et al.

Lee $e$ al ${ }^{27}$ showed that Alloy 600 exhibits a maximum in SCC susceptibility at $\sim 8$ to $17 \mathrm{scc} / \mathrm{kg} \mathrm{H}_{2}$ at $330^{\circ} \mathrm{C}$. Thus, the location of the SCC susceptibility maximum in their work is very similar to the location of the measured $\mathrm{Ni} / \mathrm{NiO}$ phase transition, which is $\sim 11 \mathrm{scc} / \mathrm{kg} \mathrm{H}_{2}$ at $330^{\circ} \mathrm{C}$ (Figure 3). In their work, the magnitude of the effect was slightly higher $(\sim 4.3 \mathrm{x})$, as compared to $\sim 2.8 \mathrm{x}$ reported in reference 4 for Alloy 600 .

Alloy X-750 Condition AH at $316^{\circ} \mathrm{C}$ : Prior work ${ }^{4}$ on Alloy X-750 AH was conducted at $338^{\circ} \mathrm{C}$ at an initial $\mathrm{K}_{\mathrm{I}}$ value of $27.5 \mathrm{MPa} \vee \mathrm{m}$. As described in Reference 4, a correlation was developed for the SCCGR of Alloy X-750 AH, using the parameter $\mathrm{ECP}_{\mathrm{N} \text { NiO }}$ - EcP. Similar to the situation discussed above for Alloy 600, it is important to investigate whether this correlation extrapolates correctly to lower temperatures. Figure 8 shows SCCGR data for Alloy X-750 AH. The circular symbols represent the prior data ${ }^{4}$, which was generated at $338^{\circ} \mathrm{C}$. The diamond symbols are new data generated at $316^{\circ} \mathrm{C}$, at hydrogen levels of 2,10 , and $60 \mathrm{scc} / \mathrm{kg} \mathrm{H}_{2}$. In terms of the magnitude of the $\mathrm{H}_{2}$ effect at $316^{\circ} \mathrm{C}$, the SCCGR at $2 \mathrm{scc} / \mathrm{kg} \mathrm{H} \mathrm{H}_{2}(1.6 \mathrm{mils} /$ day) is $\sim 6.7 \mathrm{x}$ greater than the SCCGR measured at $60 \mathrm{scc} / \mathrm{kg} \mathrm{H} \mathrm{H}_{2}(0.24 \mathrm{mils} / \mathrm{day})$. Thus, the magnitude of the $\mathrm{H}_{2}$ effect is similar to that reported at $338^{\circ} \mathrm{C}(\sim 7.2 \mathrm{x}){ }^{4}$ As was observed previously, ${ }^{4}$ the maximum in SCC susceptibility for Alloy X-750 AH resides slightly into the nickel oxide regime. It is speculate ${ }^{15}$ that this result may be due to the fact that the oxide near the crack tip in Alloy X$750 \mathrm{AH}$ tends to be $(\mathrm{Ni}, \mathrm{Nb}, \mathrm{Ti}) \mathrm{O}$, in contrast to the cubic $\mathrm{NiO}$ structure (i.e., $(\mathrm{Ni}, \mathrm{Cr}, \mathrm{Fe}) \mathrm{O}$ ) often found as the crack tip oxide in Alloys 600 and X-750 HTH. Overall, the data sets are in good agreement, and the correlation developed for $\mathrm{X}-750 \mathrm{AH}$ based on testing at $338^{\circ} \mathrm{C}$ is also appropriate for the $316^{\circ} \mathrm{C}$ data.

EN82H Weld Metal at $338^{\circ} \mathrm{C}$ : It was shown previously ${ }^{21}$ using a limited data set that the hydrogen functionality of EN82H SCCGR is qualitatively consistent with the behavior observed for other nickel-based alloys. Specifically, for tests conducted at $338^{\circ} \mathrm{C}$, faster SCCGRs were obtained at $20 \mathrm{scc} / \mathrm{kg} \mathrm{H}$ than at $40 \mathrm{scc} / \mathrm{kg} \mathrm{H}$ using the same heat of weld material. Since the measured $\mathrm{Ni} / \mathrm{NiO}$ phase transition at $338^{\circ} \mathrm{C}$ is $13.8 \mathrm{scc} / \mathrm{kg} \mathrm{H}$, the data are consistent with the observation that SCCGRs tend to increase as the phase transition is approached. However, insufficient data were available in that study to quantitatively evaluate the effect of hydrogen on the SCCGR of EN82H.

In the present work, testing was conducted at $338^{\circ} \mathrm{C}$, at an initial $\mathrm{K}_{\mathrm{I}}$ value of $38.5 \mathrm{MPa} \sqrt{\mathrm{m}}$. As shown in Figure 9, EN82H exhibits the typical maximum in PWSCC susceptibility at an intermediate hydrogen level. In this case, the maximum in SCCGR was measured at $8 \mathrm{scc} / \mathrm{kg} \mathrm{H}$. This value is in close proximity to the measured $\mathrm{Ni} / \mathrm{NiO}$ phase transition at $338^{\circ} \mathrm{C}$ (i.e., $13.8 \mathrm{scc} / \mathrm{kg} \mathrm{H}$ ). The magnitude of the $\mathrm{H}_{2}$ effect is quite significant for EN82H. In fact, the SCCGR at $8 \mathrm{scc} / \mathrm{kg} \mathrm{H}_{2}$ is $\sim 8.1 \mathrm{x}$ higher than at $60 \mathrm{scc} / \mathrm{kg} \mathrm{H}_{2}$, which is well into the nickel metal regime. Note that the data are normalized to the SCCGR at $60 \mathrm{scc} / \mathrm{kg} \mathrm{H}_{2}\left(0.21\right.$ mils/day) rather than to the SCCGR at $120 \mathrm{scc} / \mathrm{kg} \mathrm{H}_{2}$, since there is less confidence in the latter data point due to a lesser amount of SCC extension during the test.

In Figure 10, the SCCGR data are correlated using the electrochemical potential of each data point relative to the EcP of the nickel/nickel oxide phase transition. Note that the data point for the nitrogen-deaerated condition $\left(\sim 0.1 \mathrm{scc} / \mathrm{kg} \mathrm{H}_{2}\right)$ was normalized using an $\mathrm{EcP}$ value obtained from the yttria-stabilized zirconia/iron-iron oxide electrode. The correlation reasonably describes the data, and the maximum is located slightly $(\sim 10 \mathrm{mV})$ into the nickel oxide regime. The EN82H SCCGR- $\mathrm{H}_{2}$ correlation is provided in Table 5. This correlation, in combination with the updated thermodynamic model for the $\mathrm{Ni} / \mathrm{NiO}$ phase transition described earlier, can be used to extrapolate the EN82H SCCGR- $\mathrm{H}_{2}$ effects over a relatively wide range of temperatures (e.g., 260 to $360^{\circ} \mathrm{C}$ ).

Construction of plots using the $E c P_{\text {NiNiO }}-E c P$ Scale: Details for how to calculate the potential difference used in the $\mathrm{x}$-axis of Figure 7 are provided in Reference 20. Briefly, the Nernst equation can be used to demonstrate that:

$$
E c P_{N i / N i O}-E c P=1000 \cdot \frac{R T}{2 F} \cdot \ln \left(\frac{\left[H_{2}\right]_{\text {test }}}{\left[H_{2}\right]_{N i / N i O}}\right)-\left(E c P_{N i-a l l o y}-E c P_{P_{t}}\right)
$$

where $R$ and $T$ have been defined previously, $F$ is Faraday's constant $(96,500 \mathrm{C} / \mathrm{eq}),\left[\mathrm{H}_{2}\right]_{\text {test }}$ is the test hydrogen concentration, and $\left[\mathrm{H}_{2}\right]_{\text {NiNiO }}$ is the hydrogen concentration of the $\mathrm{N} \mathrm{i} / \mathrm{NiO}$ phase transition (see Figure 3 ). In equation [5], $\triangle \mathrm{EcP}$ was improved by subtracting the measured specimen-to-Pt EcP measurement (i.e., $E c P_{N_{i-a d l o y}}-E_{c} P_{P_{i}}$ ). 
This modification corrects the specimen EcP for deviations from that of a true hydrogen electrode. This correction can become appreciable at hydrogen concentrations less than $\sim 5 \mathrm{scc} / \mathrm{kg}^{3,4,20}$ as shown in Figure 11, which summarizes $\mathrm{EcP}-\mathrm{EcP}_{\mathrm{Pt}}$ data for nickel and nickel-based alloys at several temperatures. This plot ${ }^{20}$ has been updated to include $\mathrm{EcP}$ data for $\mathrm{EN} 82 \mathrm{H}$ at $338^{\circ} \mathrm{C}$, Alloys 600 and $\mathrm{X}-750 \mathrm{AH}$ at $316^{\circ} \mathrm{C}$, and nickel at $260^{\circ} \mathrm{C}$. In general, all of these materials exhibit hydrogen electrode behavior above $\sim 5 \mathrm{scc} / \mathrm{kg} \mathrm{H}$. Below this value, the nickel alloys tend to exhibit reducing potentials relative to platinum. At high hydrogen levels, the dominant anodic reaction on both platinum and nickel alloys is hydrogen oxidation, and thus all of the metals exhibit hydrogen electrode behavior. It is believed that at relatively low hydrogen levels, the corrosion reaction on the nickel alloys becomes significant, and a mixed potential develops. This issue is discussed in detail elsewhere. ${ }^{20}$

The practical consequence of this result is that for $\left[\mathrm{H}_{2}\right]>5 \mathrm{scc} / \mathrm{kg}$, the Nemst equation for a hydrogen electrode is an excellent approximation of the $\mathrm{EcP}$ of a nickel alloy. However, below this point, the EcP of the material of interest should be measured relative to platinum if at all possible. In cases where one wishes to calculate $\triangle \mathrm{EcP}$ using equation [5] but $\mathrm{EcP}-\mathrm{EcP}_{\mathrm{P}_{t}}$ data are unavailable, the empirical fit in Figure 11 can be used to estimate the deviation of the nickel alloys from hydrogen electrode behavior. Regression to the nickel alloy data yielded the following:

$$
\begin{array}{ll}
E c P_{N i-\text { alloy }}-E c P_{P t}(m V)=21.1 \cdot \ln \left[\mathrm{H}_{2}\right]-37.4 & {\left[\mathrm{H}_{2}\right]<5 \mathrm{scc} / \mathrm{kg}} \\
E c P_{\mathrm{Ni} \text {-alloy }}-E c P_{P t}(m \mathrm{~V})=-3.5 \mathrm{mV} & {\left[\mathrm{H}_{2}\right] \geq 5 \mathrm{scc} / \mathrm{kg}}
\end{array}
$$

One interesting observation, as made previously ${ }^{20}$, is that for nickel, hydrogen electrode behavior seems to persist to lower $\mathrm{H}_{2}$ levels than for the nickel alloys. It is not unreasonable to expect some differences in EcP behavior given the different elemental composition, corrosion behavior and oxides formed on nickel compared to the nickel alloys. Specifically, this result may be attributable to the absence of elements more electrochemically active than $\mathrm{Ni}$ (e.g., $\mathrm{Fe}, \mathrm{Cr}$ ) in the pure nickel specimens, since the standard potential for $\mathrm{Ni}$ is very close to that of a hydrogen electrode.

\section{Updated SCCGR-Hydrogen Correlations}

As was performed in Reference 4, a set of phenomenological correlations for the SCCGR- $\mathrm{H}_{2}$ functionality were developed using the fundamental independent parameter $\triangle \mathrm{EcP}$ and a symmetric exponential function:

$$
\frac{S C C G R}{S C C G R_{\min }}=\left(\frac{S C C G R_{\max }}{S C C G R_{\min }}\right) \cdot \exp \left(-0.5 \cdot\left[\frac{\Delta E c P+\Delta E c P_{o}}{\lambda}\right]^{2}\right)
$$

where $S C C G R_{\operatorname{mar}} S C C G R_{\min }$ is the ratio of the observed maximum to minimum crack growth rate for a given material. This ratio describes the magnitude of the SCCGR- $\mathrm{H}_{2}$ effect for a specific material (e.g., $\sim 8.1 \mathrm{x}$ for EN82H, as shown in Figure 10). $\triangle E c P$ is the distance of the condition of interest from the $\mathrm{Ni} / \mathrm{NiO}$ phase transition, calculated via equation [5]. $\triangle E c P_{o}$ is a fitted parameter which describes the extent to which the maximum crack growth rate is offset from $\triangle E c P=O$ (i.e., the location of the $\mathrm{Ni} / \mathrm{NiO}$ phase transition). $\lambda$ is another fitting parameter, which describes the breadth of the SCCGR vs. $\triangle \mathrm{EcP}$ peaks. Values for $\triangle E c P_{o}$ and $\lambda$ were obtained by linear regression analysis of a linearized version of equation [6]. Resulting values of $\triangle E c P_{o}$ and $\lambda$ are given in Table 6 for EN82H weld material, wrought Alloy 600, Alloy X-750 HTH, and Alloy X-750 AH. Note that the correlations provided in Reference 4 have been updated to reflect the new Ni/NiO correlation shown in Figures 3 and 4 .

The correlations generated in the present study can be extended to a three-dimensional basis $\left(\right.$ SCCGR- $\mathrm{H}_{2}-\mathrm{T}$ ) through the use of appropriate thermal activation energy $\left(Q_{S C C G R}\right)$ values. Figure 12 shows a 3-D plot of the EN82H correlation in temperature-hydrogen-SCCGR space. This plot was constructed using a $Q_{S C C G R}$ value of $130 \mathrm{~kJ} / \mathrm{mole}$, which has been shown to be a reasonable value for Alloy 600 weld metal. ${ }^{21,28,29}$ Henry's law coefficients from Table 4 were used to construct this plot, and an additional temperature $\left(349^{\circ} \mathrm{C}\right)$ was added to make the plot more readable. 


\section{Mitigation}

The present study shows that $\$ C C$ can be mitigated by adjusting the aqueous hydrogen level and temperature such that the condition of interest resides far from the $\mathrm{Ni} / \mathrm{NiO}$ phase transition. In a single-temperature situation, this condition can be achieved by adjusting the aqueous hydrogen level such that it is either significantly higher or significantly lower than $\left[\mathrm{H}_{2}\right]_{\text {NiNio }}$ at the temperature of interest. In a multi-temperature system, it is important that the hydrogen level to mitigate $\mathrm{SCC}$ be selected such that it does not minimize SCC for one temperature but accelerate it at another. Reducing hydrogen to relatively low levels (i.e., $\left[\mathrm{H}_{2}\right] \ll\left[\mathrm{H}_{2}\right]_{\mathrm{NiNiO}}$ ) may be a viable approach in some cases, though there are some issues to consider. For example, the SCC benefit must be balanced with the need to maintain a reducing condition to minimize overall corrosion of plant materials. In a case suçh as that of EN82H, the mitigation range appears to be much more narrow at low hydrogen concentrations than at high hydrogen concentrations. Also, as observed in Figure 11, due to the nature of the temperature-dependence of the $\mathrm{Ni} / \mathrm{NiO}$ phase transition, there is a much wider hydrogen space available on the nickel metal side of the phase transition than on the nickel oxide side of the transition as the temperature of interest decreases. Thus, while adjusting to low hydrogen levels may be beneficial in some cases, the authors believe that there are more advantages to adjusting the hydrogen level to higher levels.

An Illustration of the Benefits of Modifying the $\mathrm{H}_{2}$ Level: Figure 12 can be used to quantitatively demonstrate the benefit of higher hydrogen levels for SCC mitigation. Specifically, if one postulates an initial condition of $25 \mathrm{scc} / \mathrm{kg}$ $\mathrm{H}_{2}$ at $325^{\circ} \mathrm{C}$ (point A in Figure 11), the calculated SCCGR for EN82H is $0.39 \mathrm{mils} /$ day. If one were to isothermally adjust the hydrogen level to $50 \mathrm{scc} / \mathrm{kg} \mathrm{H}_{2}$ (point $\mathrm{B}$ ), the calculated SCCGR is $0.11 \mathrm{mils} / \mathrm{day}$, which represents a decrease of $\sim 3.5 \mathrm{x}$. This benefit is significant, as can be seen by comparing the temperature reduction that would be needed to produce a similar benefit. Using a thermal activation energy of $130 \mathrm{~kJ} /$ mole, ${ }^{21,28,29}$ the temperature would have to be reduced from $325^{\circ} \mathrm{C}$ to $297^{\circ} \mathrm{C}$ (point C) to decrease the SCCGR by a factor of $3.5 \mathrm{x}$. This example illustrates the concept that adjusting the hydrogen level has the possibility of reducing SCC similar to that of a significant reduction in temperature. Adjusting $\mathrm{H}_{2}$ may be more practical in many cases than reducing temperature.

Note that while all of the data discussed herein refer to crack growth, a similar $\mathbf{H}_{2}$ functionality has been shown for the CERT specimens of Totsuka et al., ${ }^{10}$ which include both initiation and growth. Thus, on the basis of Figure 7 , it is expected that adjusting the $\mathrm{H}_{2}$ level to mitigate crack growth would not have an adverse effect on SCC initiation.

\section{Fundamental Understanding}

The understanding of aqueous hydrogen effects has been greatly advanced by the recognition of the role of the $\mathrm{Ni} / \mathrm{NiO}$ phase transition, and by the quantification of the location of the phase transition. It is well-known in SCC of many metal-environment systems that cracking propensity can be high in the region near an oxide phase transition, presumably due to the metastability of oxides. However, important questions remain. The specific changes in the oxide composition or in the corrosion tendency of the material as the phase transition is approach are not known with certainty. It is reasonable to believe that as one moves further into the nickel metal regime, oxides may become more chromium-rich and hence more protective. It is not as clear why SCC susceptibility decreases at very low hydrogen levels.

Also, it is not evident why each material exhibits an apparently different magnitude of the aqueous hydrogen effect. The magnitude of the hydrogen effect does not appear to correlate with overall SCC susceptibility, yield strength, chromium concentration, grain size, or many other typical material parameters. One aspect of these materials that might play a role is the differing grain boundary carbides experienced in different nickel-based alloys. Specifically, Alloy X-750 HTH tends to contain $\mathrm{Cr}_{23} \mathrm{C}_{6}$ carbides, Alloy X-750 AH contains (Nb, Ti)C carbides, Alloy 600 contains $\mathrm{Cr}_{7} \mathrm{C}_{3}$ carbides, and $\mathrm{EN} 82 \mathrm{H}$ tends to contain both $\mathrm{Cr}_{23} \mathrm{C}_{6}$ and $\mathrm{NbC}$ carbides. It is possible that grain boundary carbide type influences the oxides formed, localized corrosion, and/or hydrogen recombination within SCC cracks. Further study is needed to resolve the issue of what phenomena give rise to the differing magnitudes of the SCCGR- $\mathrm{H}_{2}$ effect for the various nickel-based alloys.

\section{Acknowledgements}

Mark Ando and Horace Williams performed most of the testing described in this work. Thanks also to John Wuthrich for technical assistance. 


\section{References}

[1] T Cassagne, B Fleury, F Vaillant, O de Bouvier, P Combrade, Proceedings of the Eighth International Symposium on Environmental Degradation of Materials in Nuclear Power Systems, p. 307, 1997.

[2] G Economy, RJ Jacko and FW Pement, Corrosion, 43, No. 12, p. 727, 1987.

[3] DS Morton, SA Attanasio, JS Fish and MK Schurman, CORROSION/99 Paper No. 447, April 1999.

[4] DS Morton, SA Attanasio, GA Young, and MA Ando, Proceedings of the Tenth International Symposium on Environmental Degradation of Materials in Nuclear Power Systems-Water Reactors, Lake Tahoe, 2001.

[5] JM Boursier, O de Bouvier, JM Gras, D Noel, R Rios and F Vaillant, Proceedings of the Conference on Corrosion Deformation Interactions, p. 117, Les editions de Physique, Paris, France (1992).

[6] DS Morton, SA Attanasio, GA Young, PL Andresen, TM Angeliu, CORROSION/01, Paper No. 117, 2001.

[7] RS Pathania, AR McIlree, Proceedings of the Third International Symposium on Environmental Degradation of Materials in Nuclear Power Systems-Water Reactors, p.551, 1987.

[8] T Magnin, JM Boursier, D Noel, F Valliant, Proceedings of the Sixth International Symposium on Environmental Degradation of Materials in Nuclear Power Systems-Water Reactors, p.669, 1993.

[9] T Cassagne, A Gelpi, Proceedings of the Sixth International Symposium on Environmental Degradation of Materials in Nuclear Power Systems-Water Reactors, p.679, 1993.

[10] N Totsuka, Y Nishikawa, and N Nakajima, CORROSION/2002, Paper 523, 2002

[11] N Totsuka, E Lunarska, G Cragnolino and Z Szklarska-Smialowska, Corrosion, 53, 505 (1997).

[12] PM Scott, "Predictions of Alloy 600 Component Failures in PWR Systems", Proceedings of a Research Topical Symposium at CORROSION/96, p. 135.

[13] JS Fish, N Lewis, WJS Yang, DJ Perry, C.D. Thompson, Proceedings of the Eighth International Symposium on Environmental Degradation of Materials in Nuclear Power Systems-Water Reactors, p.266, 1997.

[14] N Lewis, SA Attanasio, DS Morton and GA Young, in "Chemistry and Electrochemistry of Corrosion and Stress Corrosion Cracking: A Symposium Honoring the Contributions of RW Staehle”, TMS, February 2001.

[15] SA Attanasio, DS Morton, MA Ando, NF Panayotou and CD Thompson, from Proceedings of the Tenth International Symposium on Environmental Degradation of Materials in Nuclear Power Systems-Water Reactors, Lake Tahoe, 2001.

[16] SE Ziemniak, ME Jones, KES Combs, Journal of Solution Chemistry, Vol. 24, p. 837, 1995.

[17] T Saario and V Marichev, EPRI IGA/SCC Workshop, San Antonio, Texas, December 1992.

[18] U. Ehrnsten, T Saario, T Laitinen and J Lagerstrom, Fourth EPRI Workshop on PWSCC of Alloy 600 in PWRs, Daytona Beach, FL, February 25-27, 1997.

[19] T Saario, Ph.D. Thesis, Helsinki University of Technology, October 1995.

[20] SA Attanasio, DS Morton, and MA Ando, CORROSION/2002, Paper No. 517, 2002.

[21] SA Attanasio, JV Mullen, JW Wuthrich, WW Wilkening, and DS Morton, NRC/Argonne Workshop on Vessel Head Penetration Inspection, Cracking, and Repairs, March 2003.

[22] DS Morton, D Gladding, MK Schurman, CD Thompson, Proceedings of the Eighth International Symposium on Environmental Degradation of Materials in Nuclear Power Systems-Water Reactors, p.387, 1997.

[23] WC Moshier and RC Witt, unpublished data, 2002.

[24] The ASME Handbook on Water Technology for Thermal Power Systems, P Cohen, ed., ASME, NY, 1989.

[25] SE Ziemniak, Journal of Solution Chemistry, Vol. 21, No. 8, p. 745, 1992.

[26] GP Airey, EPRINP-3051, Final report, EPRI, Palo Alto, CA, 1983.

[27] PM Rosecrans, Ph.D. Thesis, Renssalaer Polytechnic Institute, 1998.

[28] DH Lee, MS Choi and UC Kim, from Proceedings of the Tenth International Symposium on Environmental Degradation of Materials in Nuclear Power Systems-Water Reactors, Lake Tahoe, 2001.

[29] S Le Hong, JM Boursier, C Amzallag, and J Daret, from Proceedings of the Tenth International Conference on the Environmental Degradation of Materials in Nuclear Power Systems - Water Reactors, Lake Tahoe, NV, August 2001.

[30] WJ Mills and CM Brown, Bechtel report B-T-3435, March 2002. 
Table 1. EN82H Material Composition (in weight percent).

\begin{tabular}{|c|c|c|c|c|c|c|c|c|c|c|c|c|c|}
\hline $\mathrm{Ni}+\mathrm{Co}_{0}$ & $\mathrm{Co}$ & $\mathrm{Cr}$ & $\mathrm{Fe}$ & $\mathrm{C}$ & $\mathbf{M n}$ & $\mathrm{S}$ & $\mathrm{Si}$ & $\mathbf{C u}$ & $\mathbf{P b}$ & $\mathbf{T i}$ & $\mathbf{N b}+\mathbf{T a}$ & $\mathrm{Ta}$ & $\mathbf{P}$ \\
\hline 71.0 & N/A & 21.8 & 0.64 & 0.04 & 3.05 & 0.003 & 0.10 & 0.04 & 0.003 & 0.49 & 2.5 & 0.07 & 0.002 \\
\hline
\end{tabular}

Table 2. Film formation and reduction data measured via CER testing using a nickel specimen at $260^{\circ} \mathrm{C}$.

\begin{tabular}{|c|c|c|c|c|c|c|c|}
\hline $\begin{array}{c}\text { Test } \\
\#\end{array}$ & Temperature & $\begin{array}{c}\text { Autoclave } \\
\text { Pressure } \\
\text { (psig) }\end{array}$ & Test Phase & $\begin{array}{c}\text { Dissolved } \\
\mathbf{H}_{\mathbf{L}} \text { level } \\
\text { (sce/kg) }\end{array}$ & $\begin{array}{c}\text { EcP vs. Pt } \\
\text { (V) }\end{array}$ & $\begin{array}{l}\text { Time interval } \\
\text { (hours) }\end{array}$ & Result \\
\hline \multirow{6}{*}{$\mathrm{Ni}-260$} & \multirow{6}{*}{$260^{\circ} \mathrm{C}$} & \multirow{6}{*}{1000} & $\mathrm{Ni}-260.1$ & 60 & -0.003 & 0 to 47 & No film formation \\
\hline & & & $\mathrm{Ni}-260.2$ & 30 & -0.001 & 47 to 384 & No film formation \\
\hline & & & $\mathrm{Ni}-260.3$ & 5 & $+0,001$ & 384 to 838 & No film formation \\
\hline & & & $\mathrm{Ni}-260.4$ & 2 & +0.001 & 838 to 984 & No film formation \\
\hline & & & $\mathrm{Ni}-260.5$ & 1 & +0.001 & 984 to 1462 & Film formation \\
\hline & & & Ni-260.6 & 3 & $\mathrm{~N} / \mathrm{A}$ & 1462 to 1516 & 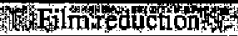 \\
\hline
\end{tabular}

Table 3. Nickel oxidation and reduction data measured via CER testing using an Alloy 600 specimen at $316^{\circ} \mathrm{C}$.

\begin{tabular}{|c|c|c|c|c|c|c|}
\hline $\begin{array}{c}\text { Test } \\
\#\end{array}$ & Temperature & $\begin{array}{c}\text { Autoclave } \\
\text { Pressure } \\
\text { (psig) }\end{array}$ & Test Phase & $\begin{array}{c}\text { Dissolved } \\
\mathrm{H}_{2} \text { leve] } \\
\text { (sce/kg) }\end{array}$ & $\begin{array}{c}\text { Time interva] } \\
\text { (hours) }\end{array}$ & Results \\
\hline \multirow{5}{*}{ A600-1 } & \multirow{5}{*}{$316^{\circ} \mathrm{C}$} & \multirow{5}{*}{3000} & A600-1.1 & 60 & 0 to 90 & Initial oxide growth \\
\hline & & & $\mathrm{A} 600-1.2$ & 20 & 90 to 165 & - \\
\hline & & & A600-1.3 & 10 & 165 to 330 & Steady-state resistance established \\
\hline & & & A600-1.4 & 5 & 330 to 478 & Signilieant oxidiztntian \\
\hline & & & A600-1.5 & 10 & 478 to 666 & WHSt \\
\hline
\end{tabular}

Table 4. Hydrogen Fugacity Data at $260^{\circ} \mathrm{C}$ (I800 psi autoclave pressure) using a Silver-Palladium Tube.

\begin{tabular}{|c|c|c|c|c|}
\hline Target $\mathbf{H}_{2}$ concentration & Henry's law coefficient & Calculated $\mathbf{H}_{2}$ Pressure & Measured $\mathbf{H}_{2}$ Pressure & Error $^{20}$ \\
\hline $60 \mathrm{scc} / \mathrm{kg}$ & $0.016 \mathrm{~atm} . /(\mathrm{scc} / \mathrm{kg})$ & $0.960 \mathrm{~atm}$. & $0.932 \mathrm{~atm}$. & $3.0 \%$ \\
\hline $30 \mathrm{scc} / \mathrm{kg}$ & $0.016 \mathrm{~atm} . /(\mathrm{scc} / \mathrm{kg})$ & $0.480 \mathrm{~atm}$ & $0.459 \mathrm{~atm}$. & $4.6 \%$ \\
\hline $5 \mathrm{scc} / \mathrm{kg}$ & $0.016 \mathrm{~atm} /(\mathrm{scc} / \mathrm{kg})$ & $0.080 \mathrm{~atm}$. & $0.078 \mathrm{~atm}$. & $2.6 \%$ \\
\hline $1 \mathrm{scc} / \mathrm{kg}$ & $0.016 \mathrm{~atm} . /(\mathrm{scc} / \mathrm{kg})$ & $0.016 \mathrm{~atm}$. & $0.017 \mathrm{~atm}$. & $5.9 \%$ \\
\hline
\end{tabular}

Table 5. Stummary data for the measured Ni/NiO phase transition, plus the predictions using the thermodynamic model

\begin{tabular}{|c|c|c|c|c|c|c|}
\hline \multicolumn{2}{|c|}{$\begin{array}{l}\text { Autoclave } \\
\text { Conditions }\end{array}$} & \multirow{2}{*}{$\begin{array}{c}\text { Henry's law } \\
\text { coefficient } \\
(\text { atm. } /(\mathrm{scc} / \mathrm{kg}))\end{array}$} & \multicolumn{2}{|c|}{ Measured Phase Transition } & \multicolumn{2}{|c|}{$\begin{array}{c}\text { Predicted Phase Transition using } \\
\text { Thermodynamic Model }\end{array}$} \\
\hline $\begin{array}{c}\mathrm{T} \\
\left({ }^{\circ} \mathrm{C}\right) \\
\end{array}$ & $\begin{array}{c}\mathrm{P} \\
(\mathrm{psi})\end{array}$ & & $\begin{array}{l}\mathrm{H}_{2} \text { Concentration } \\
\text { Busis (sec/kg) }\end{array}$ & $\begin{array}{c}\mathrm{H}_{2} \text { Fugacity Basis } \\
\text { (atm.) }\end{array}$ & $\begin{array}{l}\mathrm{H}_{2} \text { Concentration } \\
\text { Basis (sec/kg) }\end{array}$ & $\begin{array}{c}\mathrm{H}_{2} \text { Fugacity Basis } \\
\text { (atm.) }\end{array}$ \\
\hline 260 & 1000 & 0.0160 & 2 & 0.0320 & 2.0 & 0.0324 \\
\hline 288 & 1500 & 0.0122 & 4 & 0.0488 & 4.1 & 0.0497 \\
\hline 316 & 3000 & 0.0101 & 7.5 & 0.0758 & 7.3 & 0.0733 \\
\hline 338 & 3000 & 0.0072 & 13.8 & 0.0994 & 13.5 & 0.0975 \\
\hline 360 & 3200 & 0.0049 & 25 & 0.1225 & 25.9 & 0.1271 \\
\hline
\end{tabular}

Table 6. SCCGR- $\mathrm{H}_{2}$ Correlations

\begin{tabular}{|c|c|c|c|c|}
\hline $\begin{array}{c}\text { Test Material } \\
\text { and Condition }\end{array}$ & $\frac{\text { SCCGR }_{\text {max }}}{\text { SCCGR }_{\min }}$ & $\Delta$ EcP & $\lambda$ & Range of Applicability $^{\dagger}$ \\
\hline EN82H, $338^{\circ} \mathrm{C}$ & 8.09 & 10.5 & 20.2 & $-52 \mathrm{mV}<\Delta E c P<31 \mathrm{mV}$ \\
\hline Alloy $600,338^{\circ} \mathrm{C}$ & 2.81 & -10.2 & 35.6 & $-41 \mathrm{mV}<\Delta E c P<61 \mathrm{mV}$ \\
\hline Alloy X-750 HTH, $360^{\circ} \mathrm{C}$ & 4.89 & 4.2 & 20.4 & $-41 \mathrm{mV}<\Delta E c P<32 \mathrm{mV}$ \\
\hline Alloy X-750 AH, $338^{\circ} \mathrm{C}$ & 7.19 & 30.8 & 40.0 & $-110 \mathrm{mV}<\Delta \mathrm{EcP}<49 \mathrm{mV}$ \\
\hline
\end{tabular}

$\dagger$ The SCCGR effect of dissolved $H_{2}$ seems to have an appreciable infuence in a narrow range of EcP near the $N i / N i O p h a s e$ transition. 


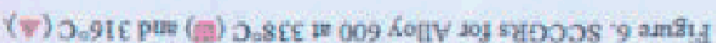

$$
\text { (Au) } \text { dP马 }^{\text {ONN }} \text { d? }
$$

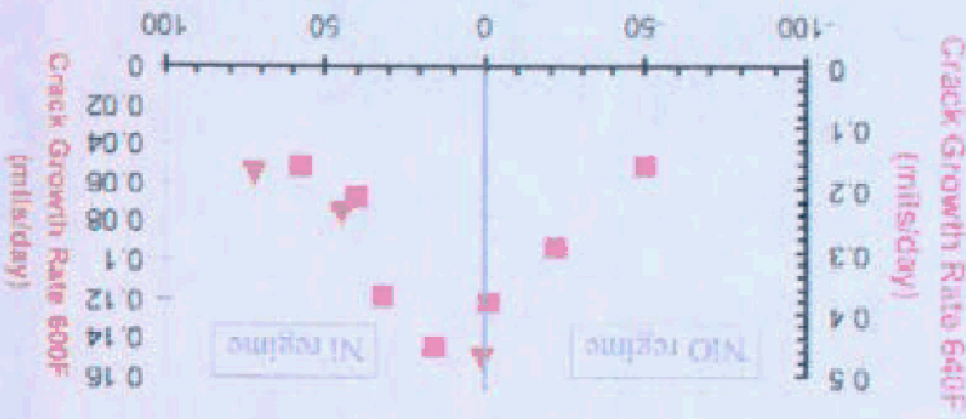

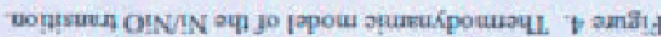

\section{$($, Y) $\perp$ L}
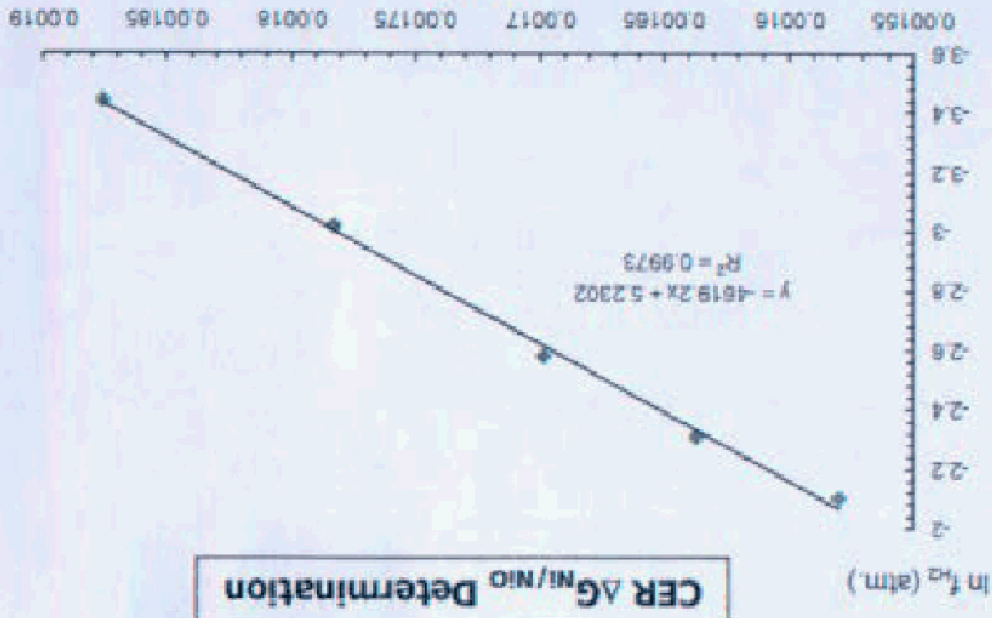

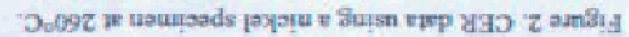

\section{(sm 04) ลat!}

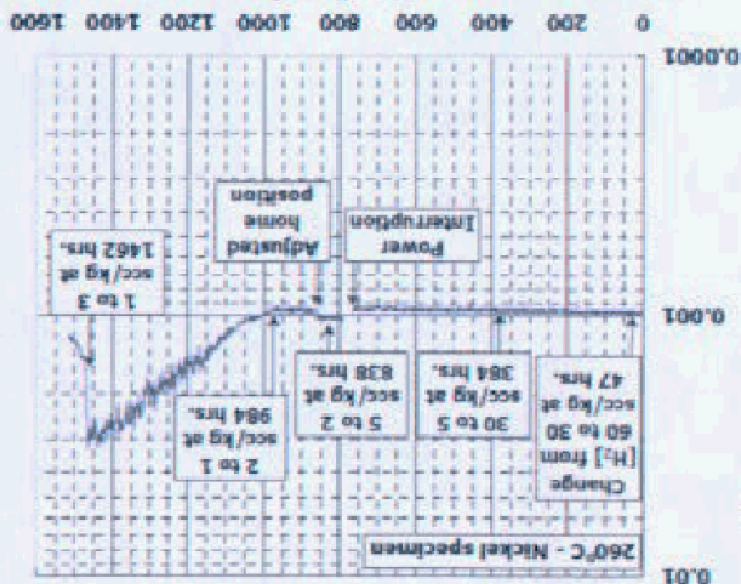

(Auqa)

anuprssay

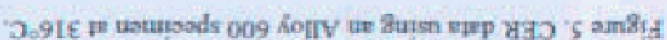

$$
\text { (cinat) aur }
$$

009 ass oos ost dot oss dor ast oot ost oat as a

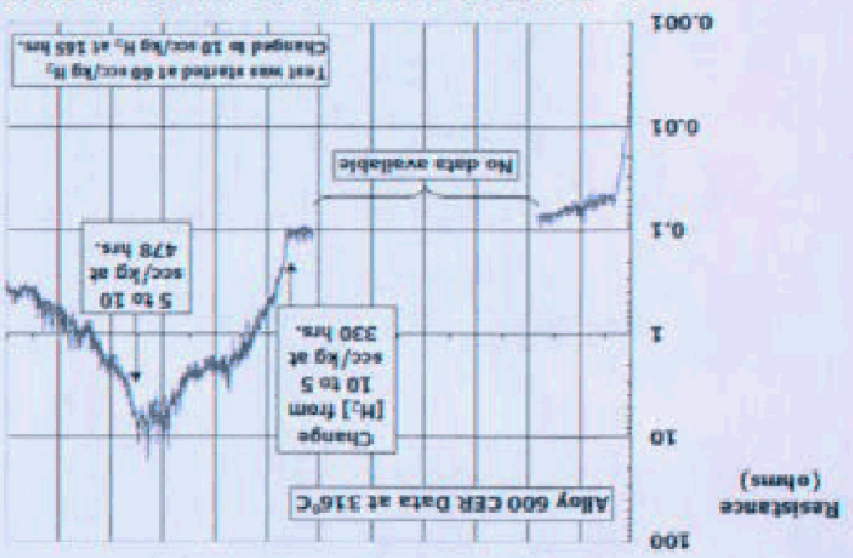

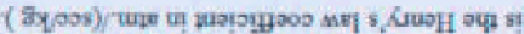

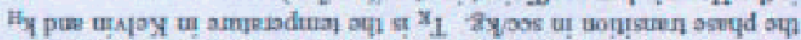

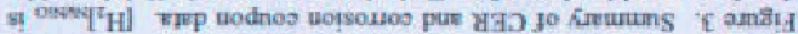

(a.) eimeisdue 1

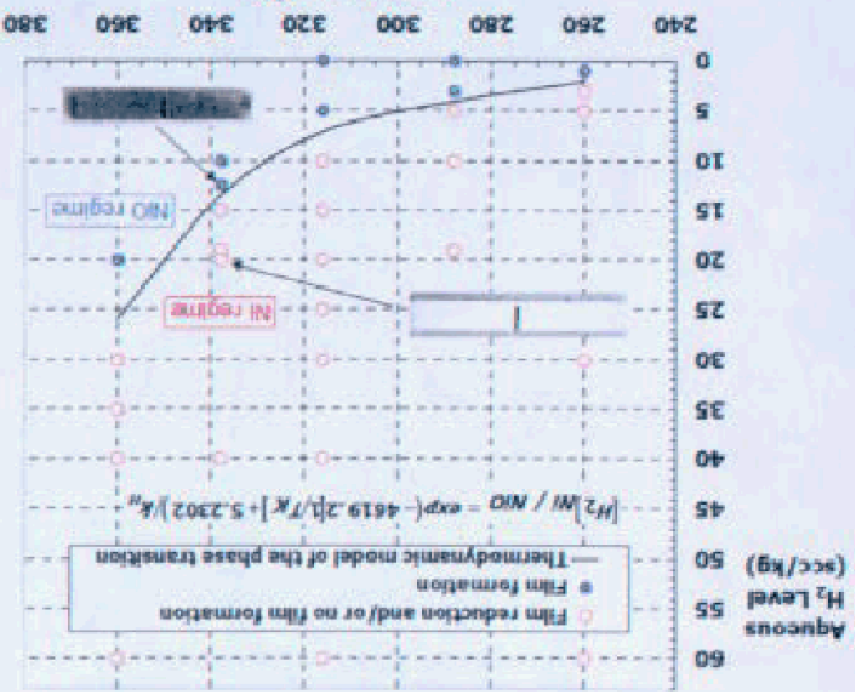

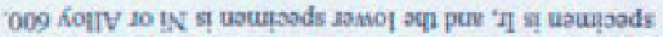

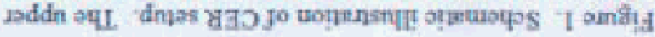

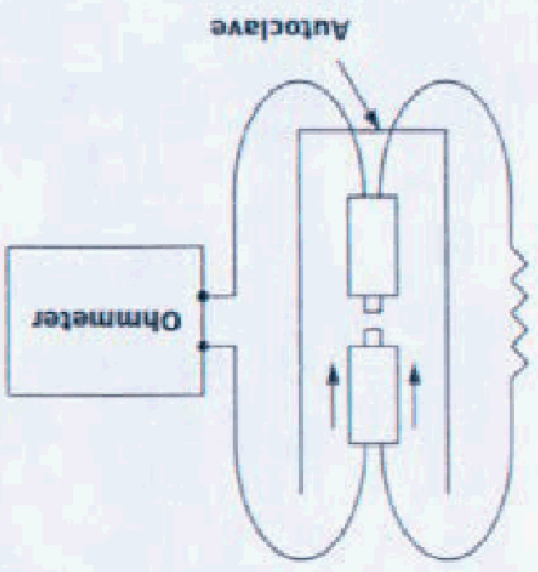




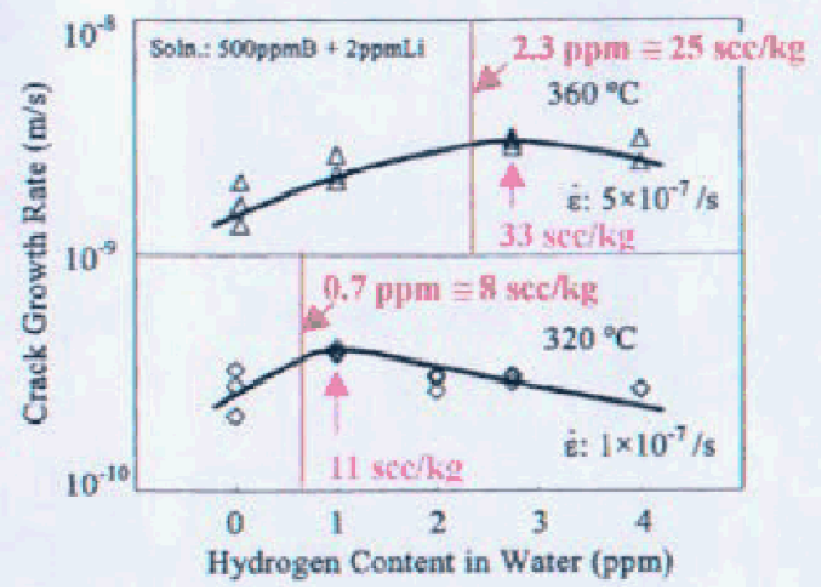

Figure 7. Alloy 600 CERT data frem Totsuka et allap

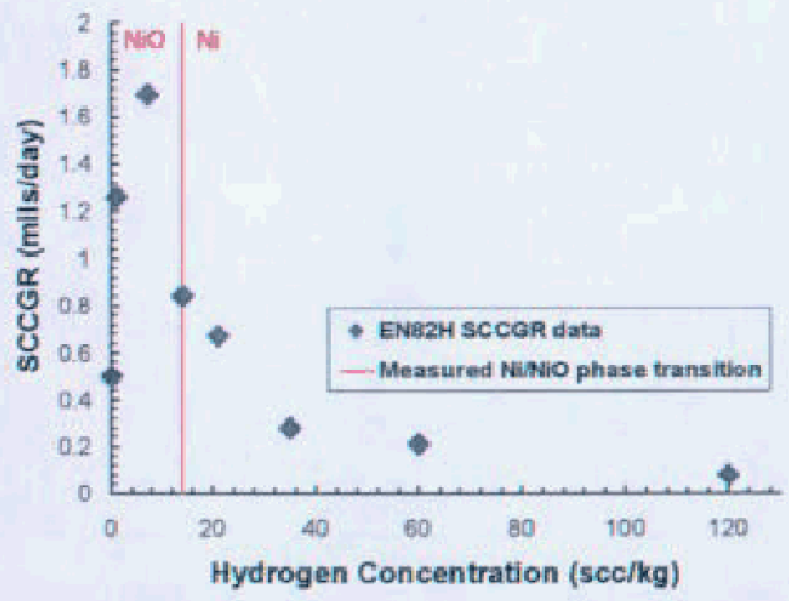

Figure 9. SCCGRs for ENs2H ai $338^{\circ} \mathrm{C}$. The measured NiNiO transition at $338^{\circ} \mathrm{C}$ is 13.8 seekg H

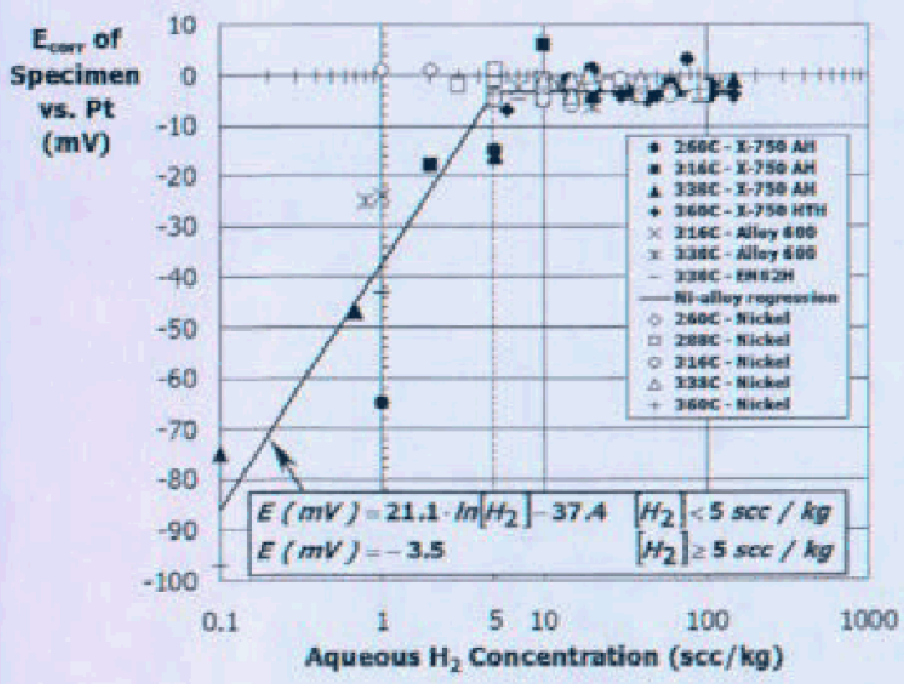

Figure 11. Eels of $\mathrm{Ni}$ and Ni-slloys relative to platinum.

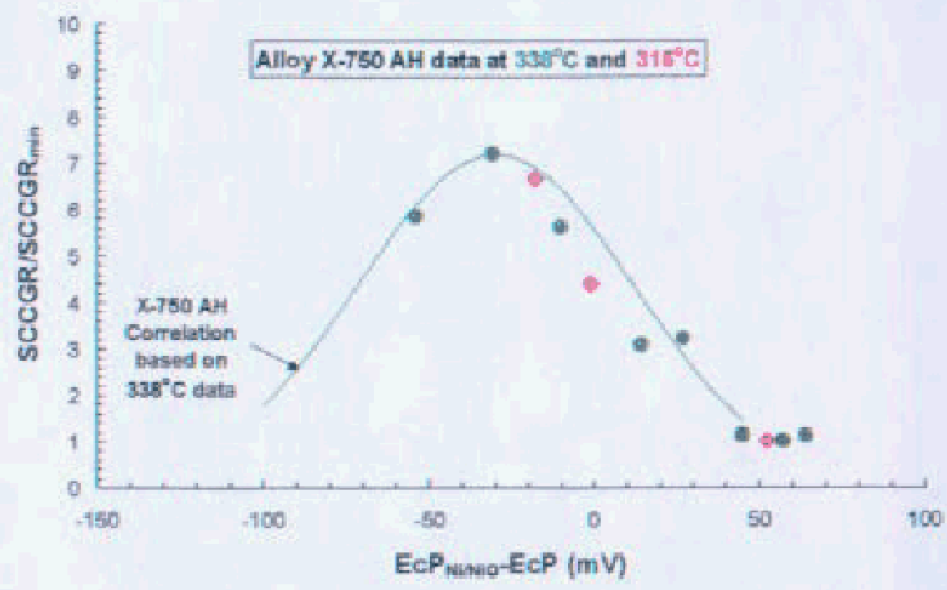

Figure 8. SCCGRs for Alloy X-750 AH at $338^{\circ} \mathrm{C}$ (6) and $316^{\circ} \mathrm{C}(\mathrm{A})$

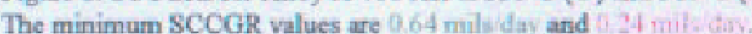

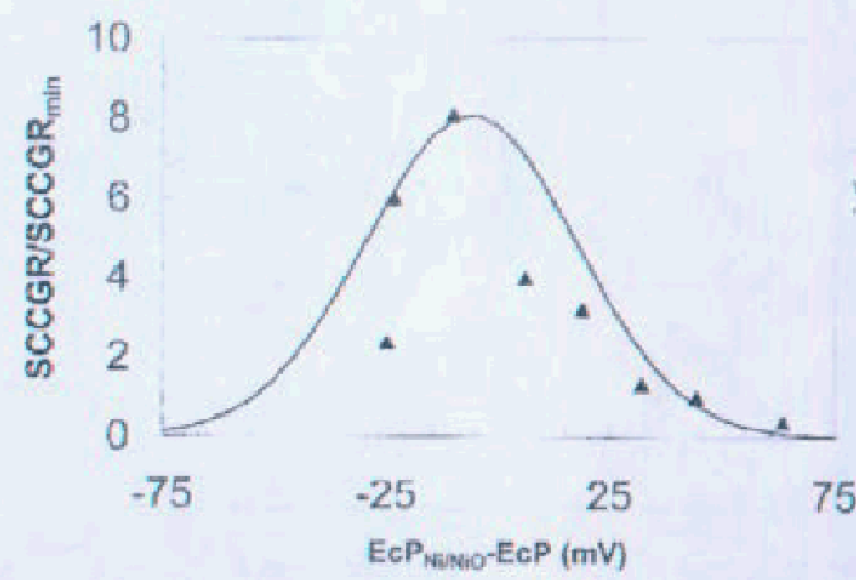

Figure 10. Nornalized data for EN82H on a $\triangle E c P$ basis. SCCGRs are nomulized to a minimum value of 0.21 mileddsy (at 60 scokg). The value for 120 sco/kg is not used due to uncertainty.

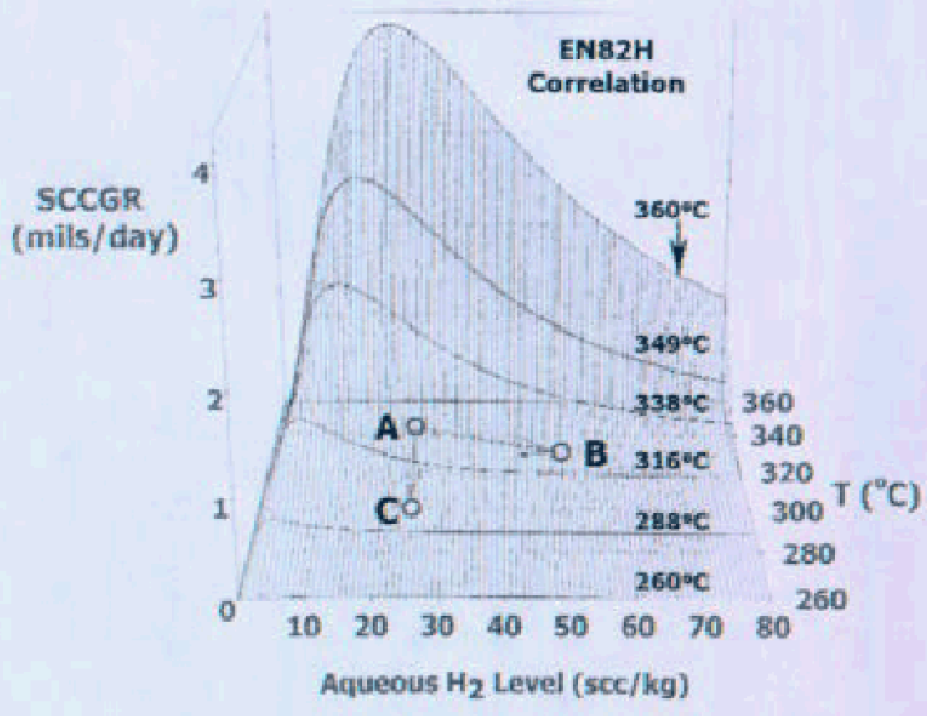

Figure 12. 3D plot of EN82H SCCGR conrelation and data. Contours are shown at $260,283,316,338,349$, and $360^{\circ} \mathrm{C}$ 